\title{
PEMBELAJARAN JARAK JAUH DALAM MASA PANDEMI COVID-19
}

\author{
Nur Najmina Rihani
}

Program Studi Pendidikan IPS, FKIP Universitas Lambung Mangkurat

\section{7@mhs.ulm.ac.id}

\begin{abstract}
ABSTRAK
Kebijakan baru dari pemerintah pada masa pandemi Corona Virus Disease (COVID-19) untuk social atau physical discanting guna mengurangi penularan virus tersebut. Termasuk pada sektor pendidikan yang harus mengikuti kebijakan baru ini, kebijakan ini membuat kegiatan di luar rumah harus dikerjakan di rumah saja. Pembelajaran jarak jauh yang dilaksakan oleh pendidikan tidak lah berjalan dengan mudah. Pembelajaran berbasis daring ini memiliki dampak juga dalam penggunaannya, sistem seperti ini memerlukan pengadaptasian yang begitu kompleks guna keefektifan belajar dalam pembelajaran jarak jauh ini tetap terlaksanakan.
\end{abstract}

\section{Kata kunci: pembelajaran, daring, dan COVID-19}

\section{PENDAHULUAN}

Pembelajaran adalah proses interaksi perserta didik dengan pendidik dan sumber belajar pada suatu lingkungan belajar yang meliputi guru dan siswa saling bertukar infomasi (Mutiani, M., Subiyakto, B., Jumriani, J., Aslamiah, A., \& Afrina, A. 2019). Pembelajaran menjadi suatu proses yang dimana tenaga pendidik melakukan pengembangan kreatifitas berpikir untuk meningkatkan berpikir peserta didik, kemudian juga meningkatkan kemampuan meningkatkan pengetahuan baru. Pembelajaran menjadi suatu upaya untuk meningkatkan penguasaan yang bagus terhadap mata pelajaran. Pada akhir Desember 2019, ditemukan Corona Virus Disease 2019 (COVID-19) DI KOTA Wuhan, China. Virus ini menyebar begitu cepat hampir ke berbagai negara, termasuk Indonesia. Munculnya virus berbahaya ini berdampak pada berbagai berbagai sektor, termasuk sektor pendidikan. Di negara Indonesia sendiri mengeluarkan kebijakan untuk memberlakukan lockdown dalam mencegah penularan, juga kebijakan Pembatasan Sosial Berskala Besar (PSBB) oleh pemerintah, dengan adanya kebijakan ini sehingga beberapa kegiatan diluar rumah diberhentikan agar mengurangi penyebaran virus.

Kemendikbud mengeluarkan berbagai kebijakan pada sektor pendidikan guna mengurangi penularan COVID-19 ini. Seperti kebijakan pemerintah untuk melakukan jaga jarak satu sama lain, sektor pendidikan melaksanakan kebijakan work from home atau kegiatan yang biasanya dilakukan di luar rumah akan dilakukan di rumah saja. kegiatan pembelajaran yang 
mulanya dilakukan dengan tatap muka, kemudian berubah menjadi pembelajaran jarak jauh atau pembelajaran secara daring. Diberlakukannya pembelajaran jarak jauh tentu menimbulkan dampak pada sektor pendidikan yang telah lama digunakan, juga berdampak pada keefektifan belajar pada peserta didik.

\section{PEMBAHASAN}

Pendidikan memiliki peran penting dalam kehidupan masyarakat secara umum, melalui proses belajar-mengajar dari lembaga formal dan informal (Janah, W. A., Abbas, E., W., \& Mutiani, M. 2020). Melalui pendidikan peserta didik mendapatkan informasi atau pengetahuan luas yang disampaikan oleh tenaga pendidik. Pendidikan merupakan wadah usaha bagi peserta didik untuk mencapai masa depan yang baik. Pelandasan pendidikan secara sederhananya diringkaskan kepada apungan critical thinking, creatifity, communitation, dan collaboration dalam konsep dan teori pendidikan. Pendidikan bukan hanya bermakna sebagai pengajaran dan pembelajaran, karena pendidikan berupaya untuk menolong anak manusia mengembangkan potensinya (Abbas, E, W., Mu'in, F., Barkatullah, A. H., Kania, N., \& Ghalib, S. 2020). Pembelajaran ialah kegiatan yang dimana tenaga pendidik melakukan penyampaian informasi atau pengetahuan kepada peserta didik. Satu diantara ciri pembelajaran yaitu memiliki tujuan, maksudnya adalah tenaga pendidik membentuk peserta didik dalam sebuah perkembangan. Kegiatan belajar mengajar adalah kegiatan yang dilakukan dengan sengaja, dalam kegiatan tersebut terdapat suatu interaksi yang dilakukan oleh tenaga pendidik dan peserta didik guna terwujudnya tujuan pembelajaran. Sebagai pendidik harus menyadari apa yang harus dilakukan pada kegiatan belajar mengajar untuk tercapainya pengantaran informasi atau pengetahuan kepada peserta didik. Pembelajaran menurut sudut pandang behavioristik merupakan sebagai proses tingkah laku peserta didik melalui mengoptimalkan lingkungan sebagai stimulus belajar (Syaharuddin, S., \& Mutiani, M. 2020).

COVID-19 memang menjadi musuh besar bagi manusia diseluruh dunia saat ini. Akibatnya, banyak kebijakan baru yang menciptakan kebiasaan baru pula. Adanya 
wabah tersebut yang membuat ancaman bagi seluruh dunia tentu membuat polemik global. Satu diantaranya adalah pendidikan, pendidikan adalah aspek yang berfungsi untuk meningkatkan sumber daya manusia (Wahyuningsih, S., Abbas, E., W. \& Mutiani, M. 2020). Corona Virus Disease 2019 atau COVID-19 telah melanda hampir di berbagai negara, termasuk Indonesia COVID-19 sangat berdampak pada bebagai sektor kehidupan, termasuk dalam dunia pendidikan. Pemerintah berupaya untuk mehindari adanya penularan virus ini dengan mengeluarkan kebijakan diberlakukannya social atau physical distancing yang telah berdampak pada kegiatan pembelajaran tatap muka secara langsung, kemudian digantikan dengan pembelajaran jarak jauh atau pembelajaran berbasis daring. Kebijakan pembelajaran ini dilaksanakan oleh jenjang pendidikan dasar, menengah hingga perguruan tinggi.

Indonesia, sebagai negara berkembang mahir secara teknologi dan siap untuk menyambut kemajuan e-learning di oraganisasi publik dan bisnis (Abbas, E. W., \& Rajiani, I. 2019). Pembelajaran berbasis daring tidaklah hal yang sulit dilakukan dalam era yang modern saat ini, dengan adanya kemajuan teknologi dan informasi yang cepat. Hampir semua tenaga pendidik dan peserta didik memiliki telepon pintar (smartphone), kemudian dengan banyaknya pilihan kemajuan forum diskusi berbasis daring atau aplikasi pembelajaran yang bisa digunakan. Seperti aplikasi zoom, goolemeet, google classroom, dan lain-lain. Pengoprasikannya tidak lah sulit sebab hampir sama saja dengan aplikasi yang umumnya kita gunakan keseharian. Dikutip dari Syaharuddin, S. (2020), peran media itu sebagai transfer of knowledge, kelemahan teknologi yaitu tidak memiliki rasa, bahasa, dan karakter. Oleh karena itu, peran ini harus menjadi milik seorang tenaga pendidik yang tidak hanya menjalankan fungsi mentransferkan ilmu pengetahuan tetapi juga mampu membentuk sikap dan perilaku sebagai tugas tenaga pendidik.

Dikutip oleh Pruto, H. P. N., \& Jumriani, J. (2020), sumber bahan pembelajaran berasal dari masyarakat sekitar, tentu hal ini merupakan sumber bahan ajar yang dekat dengan keseharian. Pembelajaran jarak jauh atau pembelajaran berbasis daring merupakan pembelajaran yang menggunakan berbasis internet, tentu saja internet 
suatu jaringan yang dekat dengan kehidupan masa kini atau bisa dikatakan sudah menjadi life style tersendiri bagi pengguna teknologi. Pembelajaran daring memerlukan proses beradaptasi dengan teknologi. Generasi peserta didik sekarang ini jauh lebih mudah melakukan adaptasi dengan keajuan tekonologi, karena generasi yamg sangat dekat dengan teknologi digital dan kemajuan informasi yang cepat didapat. Tidak hanya peserta didik yang melakukan adaptasi terhadap teknologi, akan tetapi tenaga pendidik juga harus melakukan adaptasi ini guna mempersiapkan berbagai materi dan bahan ajar kepada peserta didik. Tenaga pendidik juga akan berusaha agar peserta didik dapat menyelesaikan tugas yang diberikan tanpa harus terbebani dan tetap memperhatikan kondisi setiap peserta didik.

Dilaksanakannya pembelajaran daring, seorang peserta didik tetap mengasah pengtahuan, nilai, dan keterampilan. Lesson study sebagai solusi untuk membangun komunitas belajar (Learning Community) antar guru, peserta didik maupun akademisi. Secara khusus membantu mengontruksikan pada saat transkip dialog (Mutiani, M., Abbas, E. W., Syaharuddin, S., \& Susanto, H.). Akan tetapi, dalam proses ini masih ada beberapa kegiatan pembelajaran berbasis daring yang menimbulkan kurangnya keefektifan belajar pada peserta didik. Seperti keterbatasannya waktu dalam menjelaskan materi hingga tanya jawab, kemudian tidak semua peserta didik memiliki telepon pintar juga kurang mengerti dalam pengerjaan tugas dari pendidik. Seperti dikutip oleh Syaharuddin, S. (2020), banyak kendala yang terdapat pada pembelajaran berbasis daring, mulai dari masalah teknis hingga soal proses pembelajaran. Contohnya jaringan yang sulit di dapat, quota internet yang begitu mahal, sampai dengan pengoprasian aplikasi pembelajaran yang begitu rumit, juga kurangnya partisipasi peserta didik saat pembelajaran berlangsung melalui aplikasi.

Seiring berjalannya waktu, pembelajaran daring yang awal mulanya memerlukan adaptasi guna lancarnya pembelajaran. Akan menemui dimana rasa bosan atau malas, hal ini dikarenakan teknik pembelajaran yang kurang menarik atau tidak seru sehingga menimbulkan ketidakefektifan dalam belajar bagi peserta didik, juga kurangnya pemahaman peserta didik terhadap materi yang diberikan. Pembelajaran 
daring bisa saja menjadi mengasyikkan dengan teknik dan sumber ajar yang menarik juga mengasah kreatifitas. Di era globalisasi ini, tentu peserta didik berlomba-lomba untuk mengeluarkan potensinya masing-masing. Hal ini juga disertai dukungan oleh pendidik baik seorang guru yang memberikan materi maupun orang tua di rumah yang mengawasi peserta didik sedang belajar. Tenaga pendidik didorong untuk memberikan inovasi dalam pembelajaran berbasis internet ini agar peserta didik tetap aktif dalam pembelajaran berlangsung.

Demikian artikel pembelajaran jarak jauh pada masa pandemi COVID-19 yang dimana pembelajaran ini masih diberlakukan kepada sektor pendidikan guna memutus tali penyebaran virus. Tentu pembelajaran jarak jauh memiliki dampak yang begitu menonjol pada masyarakat, tetap mengikuti kebijakan pemerintah adalah jalan terbaik agar tidak terjadinya penularan. Gunakan kreatifitas yang lebih menarik guna menciptakan suasana pembelajaran jarak jauh tidak begitu berat. Baik hal tersebut ditujukan kepada peserta didik maupun pendidik. Pendidik perlu membangkitkan perhatian peserta didik dalam pembelajaran yang diberikan serta dapat menggunakan media dan sumber belajar yang bervariasi (Subiyakto, B., \& Akmal, H. 2020).

\section{SIMPULAN}

Berdasarkan deskripsi di atas dapat disimpulkan bahwa pembelajaran jarak jauh atau pembelajaran berbasis daring adalah kebijakan baru pemerintah pada masa pandemic COVID-19. Kebijakan pemerintah untuk tetap stay at home guna mengurangi penularan virus berbahaya yang telah melanda hamper berbagai negara, termasuk Indonesia. Pandemi COVID-19 telah mengubah beberapa sektor kehidupan di masyarakat, terutama sektor pendidikan. Sesuai kebijakan baru dari pemerintah, Kemendikbud pun melakukan perubahan pembelajaran tatap muka menjadi pembelajaran jarak jauh atau berbasis daring. Tentu pembelajaran baru ini memiliki dampak yang komplek pada peserta didik maupun tenaga pendidik, dimana tenaga pendidik memberika materi pembelajaran dengan teknik yang menarik dan mengasah kreatifitas sehingga peserta didik tidak merasa cepat bosan dalam belajar. 


\section{DAFTAR PUSTAKA}

Abbas, E, W., Mu'in, F., Barkatullah, A. H., Kania, N., \& Ghalib, S. (2020). Pidato Pengukuhan Lima Guru Besar ULM.

Abbas, E. W., \& Rajiani, I. (2019). Managing e-leaning in public universities by investigating the role of culture. Polish Journal of Management Studies, 20.

Janah, W. A., Abbas, E. W., \& Mutiani, M (2020). The Contribution of Leadership Value of Nadjmi Adhani as a Learning Resourcer on Sosial Studies. The Innovation of Social Journal, 1(2), 188-196.

Mutiani, M., Subiyakto, B., Jumriani, J., Aslamiah, A., \& Afrina (2019). Laporan Penelitian: Relevansi Modal Sosial Dalam Pembelajaran IPS (Studi Kasus Dalam Sistem Zonasi Di SMP Negeri Kota Banjarmasin).

Pruto, H. P. N., \& Jumriani, J. (2020). KEHIDUPAN SOSIAL DAN EKONOMI MASYARAKAT BANTARAN SUNGAI A SEBAGAI SUMBER BELAJAR IPS.

Subiyakto, B., \& Akmal, H. (2020). Profesi Keguruan.

Syaharuddin, S. (2020). Menimbang Peran Teknologi dan Guru dalam Pembelajaran di Era COVID-19. Menimbang Peran Teknologi dan Guru dalam Pembelajaran di Era COVID-19

Syaharuddin, S. (2020). PEMBELAJARAN MASA PANDEMI: DARI KONVENSIONAL KE DARING. PEMBELAJARAN MASA PANDEMI: DARI KONVENSIONAL KE DARING.

Syaharuddin, S., \& Mutiani, M. (2020). STRATEGI PEMBELAJARAN IPS: Konsep dan Aplikasi

Wahyuningsing, S., Abbas, E. W. \& Mutiani, M. (2020). Implementation of Leadership Value of Rudy Resnawan as a Leaning Resources on Social Studies. The Innovation of Social Studies Journal, 1(2), 169-177. 